\title{
Preliminaries to the Tuvan interrogative intonation
}

Tatiana Ryzhikova, Albina Dobrinina, Ilia Plotnikov

Institute of Philology, Siberian Branch of RAS, Russia

https://doi.org/10.36505/ExLing-2020/11/0041/000456

\begin{abstract}
Tuvan is one of the minority Turkic languages of Siberia (RF). Its segmental structure is described quite well, whereas its suprasegmental level has not been studied yet. The purpose of this paper is to give a preliminary description of the Tuvan interrogative intonation. Several topical dialogues were recorded by three Tuvan women, yes/no questions were cut out and their structure and F0 changes were analyzed. The preliminary results show that Tuvan intonation seems to closely correlate with the information structure. The interrogative particle be appears to be pronounced with different F0 movement in accordance with the utterance focus. Generally Tuvan yes/no questions prove to be characterized by inclination of the tone, though the patterns are not as strict as in Altay, for example.
\end{abstract}

Keywords: intonation, yes/no questions, Tuvan, PRAAT, endangered languages

\section{Introduction}

The Tuvan language (formerly known as Uriankhay, Soyot, Tanu-Tuvan) is the language of the indigenous population of the Tyva Republic (RF). In Russia, it is also spoken in the South of the Krasnoyarsk region. The Tuvan ethnic group is settled in Mongolia and China - in the Xinjiang Uygur Autonomous region of China (Bavuu-Syuryun 2010: 58). The total number of speakers is about 270 thousand people (estimate of 2015), including about 253.7 thousand people (2010 census) in Russia, about 10 thousand - in Mongolia, and approx. 5 thousand - in China (Simchit 2017). 98\% of Tuvinians living on the territory of Tuva consider Tuvan as a mother tongue (Bavuu-Syuryun 2010: 58).

The Tuvan language is of the agglutinative type and in accordance with the genealogical classification, it belongs to the Siberian group of the Turkic family of the Altai macrofamily of languages (Scherbak 1994: 39). In line with L. Johansons's classification it refers to the Northeastern (or Siberian), a southern, South Siberian, subbranch comprising Sayan Turkic: i.e. Tuvan, Tofan, Soyot, Dukhan, Tuhan, etc., and non-Sayan Turkic, i.e. Khakas, Shor, North Altay, Chulym, etc. (Johanson 1998). Tuvan has four dialects: Central, Western, North-Eastern (Todzhinsky) and South-Eastern. The central dialect is under consideration in this article.

If segmental structure of Tuvan is described quite well, its suprasegmental level has not been studied yet. Thus the purpose of this paper is to give a

ExLing 2020: Proceedings of 11 th International Conference of Experimental Linguistics, 12-14 October 2020, Athens, Greece 
166 T. Ryzhikova, A. Dobrinina, I. Plotnikov

preliminary description of the Tuvan intonation. The object of the study is the modal (yes/no) interrogative utterances of the native speakers of Tuvan.

\section{Methodology}

A topical dialogue was recorded by three Tuvan women. Then the interrogative utterances were cut out of the dialogue with the help of the Audacity program and their segmentation was done in PRAAT. The analysis was carried out at the syllabic level, because a syllable is the smallest unit of intonation.

The preliminary analysis of the material showed that additional microdialogues were necessary, thus the procedure was repeated with other sentences. Total amount of utterances under investigation is 74 .

\section{Results and discussion}

Intonation plays one of the leading roles in establishing information structure. It seems to be especially true for Tuvan. Sh. Sat points out that there are four ways of making questions in this language: 1 ) using special adverbs (where? from where? etc.); 2) using special pronouns (which? what? who?); 3) using special interrogative particles (be, ale (ele), aa, irge be, che, dee, ijik be, etc.); 4) using special interrogative affix $-y l$. But the author also emphasizes that question can also be made just by using special interrogative intonation (Sat 1983: 33). Thus defining topic and focus in the utterance becomes of crucial importance for establishing Tuvinian intonation patters.

Discussed below are a few examples from Tuvan:

Figure 1 illustrates the utterances Hünüvüs dunup kel'di be? - Hünüvüs deep kel'di.

The question Hünüvüs dunup kel'di be? 'Has our sun risen?' starts from 14.4 st. increasing up to 19.6 st. on the last syllable of hünüvüs, then an even tone of about 18 st. is preserved on dunup followed by a slight decrease to 16 st. on the first syllable of kel'- and then again a sharp increase on -di up to 20 st. that is kept on 19, 5 st. on the particle be.

The response Hünüvüs deep kel'di. 'Our sun has risen' is pronounced as follows: it starts at 15 st. followed by a drop to 12 st. and a last sharp increase on the last syllable of hünüvüs up to 15 st., then again a drop to 11.5 st. on deep and a slight increase to 12 st. on kel'di.

It seems possible to conclude that the question starts either at the same level as a statement or even higher, but then the intonation deviates: the question has rising movement of $\mathrm{F} 0$, whereas a statement is characterized by declination. Other examples under consideration prove this conclusion to be true.

The utterance Hüresh bolur be? 'Will there be a traditional fight?' represents a canonical yes/no question with the interrogative particle be at the end and focus on the predicate bolur (Figure 2). 
Generally, intonation is rising starting from the first word büresh up to the last syllable of bolur, and be can be pronounced either with further inclination or with declination of F0.

The utterance Üsh eves be? 'Not three times?' (Figure 3) proves the idea of Sh. Sat that the utterance can be made interrogative just by the special intonation.

Here all the sentence is a focus and inclination starts at $\ddot{i s h}$ and proceeds up to be, which can be pronounced either with a high tone or with a slight declination.
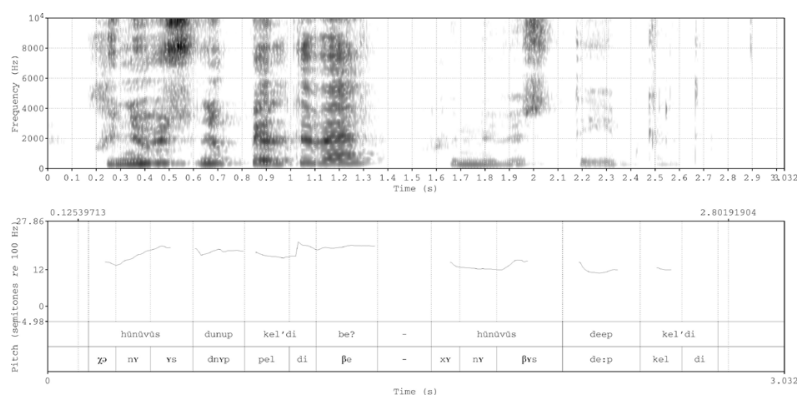

Figure 1. Intonogram of the utterance Hünüvïs dunup kel'di be? - Hünüvïs deep kel'di. 'Has our sun risen? - Our sun has risen.'
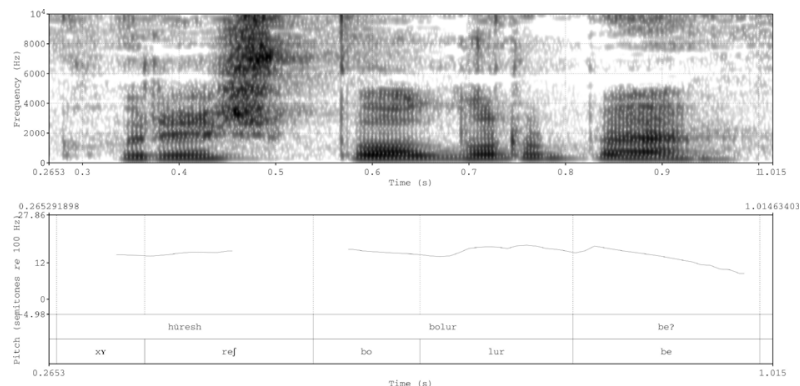

Figure 2. Intonogram of the utterance Hüresh bolur be? 'Will there be a traditional fight?'
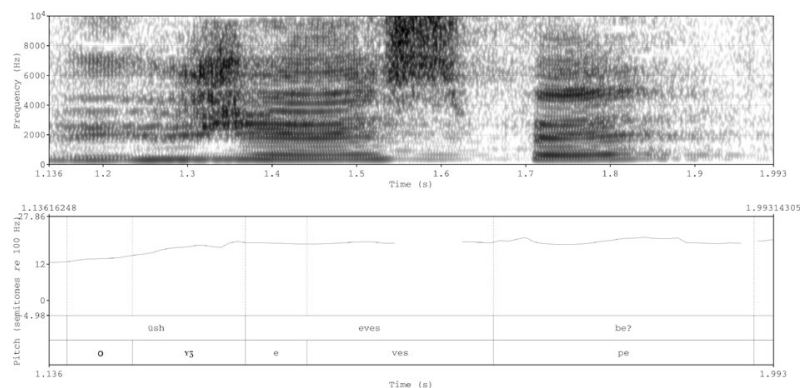

Figure 3. Intonogram of the utterance Üsh eves be? 'Not three times?' 
168 T. Ryzhikova, A. Dobrinina, I. Plotnikov

\section{Conclusions}

The analysis of the Tuvan interrogative utterances allows us to make some preliminary conclusions:

1) The Tuvan yes/no questions are formed by adding the special interrogative particles or just by using a special intonation.

2) Unlike the obligatory rise of $\mathrm{F} 0$ on the interrogative particle ba in the Altay language (see Ryzhikova et al. 2020:149-165) in Tuvan the tone on be appears to be very inconsistent: it can be pronounced either with inclination, or even high tone or declination. The later phenomenon might be possibly explained by the position of focus, but this supposition requires further investigation.

3) The interrogative particle be in Tuvan is characterized by its lengthening, the phenomenon not found in Altay, where its duration equals the average syllable length (see Ryzhikova et al. 2020:149-165).

4) Although the beginning of the utterance can be the same for the question and the statement, then their intonation contours diverge: the question is characterized by inclination whereas a statement - by declination of $\mathrm{F} 0$.

All the conclusions are preliminary and need further verification.

\section{Acknowledgements}

This research is carried out within the framework of the project of the Institute of Philology of the Siberian Branch of the Russian Academy of Sciences «Cultural universals of verbal traditions of the peoples of Siberia and the Far East: folklore, literature, language» supported by a grant from the Government of the Russian Federation for the promotion of research conducted under the guidance of leading scientists, contract № 075-15-2019-1884.

\section{References}

Bavuu-Syuryun M. 2010. Tuvan language on modern stage: educational aspect. Novye Issledovaniya Tuvy 3, 57-71.

Johanson, Lars. 1998. The History of Turkic. In Lars Johanson \& Éva Ágnes Csató (eds) The Turkic Languages. London, New York: Routledge, 81-125.

Scherbak, A. 1994. Introduction into a comparative study of the Turkic languages. Saint-Petersburg.

Simchit, A. K.-M. 2017. The Tuvan language in Big Russian Encyclopaedia; online: https://bigenc.ru/linguistics/text/4218682 Visited: 25.08.2020.

Sat, Sh. 1983. Modern Tuvan literary language. A textbook. Kyzyl. 141 p.

Ryzhikova, T., Dobrinina, A., Plotnikov, I., Shestera, E., Shamrin, A. 2020. Intonation of modal interrogative sentences in the Altai language (on the Altai-Kizhi folklore material). Siberian Journal of Philology 2, 149-165. 